\title{
SUPERVISI KEPALA MADRASAH BERBASIS PENILAIAN KINERJA SEBAGAI UPAYA PENINGKATAN PROFESIONALITAS GURU
}

\author{
Saiful Asyari \\ Kantor Kementerian Agama Kabupaten Jember \\ saifulasyari89@gmail.com
}

DOI: https://doi.org/10.35719/jieman.v2i1.14

\begin{abstract}
Abstrak
Eksistensi sebuah lembaga pendidikan terletak pada kualitas sumberdaya manusia yang dihasilkan oleh lembaga tersebut, karena pada hakikatnya berdirinya lembaga pendidikan bertujuan untuk meningkatkan kualitas sumberdaya manusia. Kajian ini difokuskan pada supervisi kepala madrasah berbasis penilaian kinerja sebagai upaya peningkatan proesionalitas guru madrasah. Tujuan penelitian ini adalah untuk membantu para guru dan pegawai di lingkungan madrasah dalam melakukan pekerjaan secara efektif dan efisien. Penelitian ini merupakan library research. Teknik pengumpulan datanya menggunakan studi dokumenter, sedangkan analisis datanya menggunakan analisis isi. Hasil penelitian ini menunjukkan bahwa dalam lembaga pendidikan, penilaian kinerja merupakan sistem formal yang digunakan untuk menilai kinerja secara periodik, dan hasilnya dapat digunakan untuk pengambilan keputusan dalam rangka pengembangan, pemberian reward, perencanaan, pemberian kompensasi dan motivasi. Hasil penilaian kinerja kepala madrasah diharapkan dapat bermanfaat untuk menentukan berbagai kebijakan yang terkait dengan peningkatan mutu. Penilaian kinerja kepala madrasah merupakan acuan bagi pengambil kebijakan atau pemangku kepentingan untuk menetapkan pengembangan karir, periodeisasi dan pengembangan keprofesian berkelanjutan. Bagi kepala madrasah, penilaian kinerja kepala madrasah merupakan acuan untuk mengetahui unsur-unsur apa saja yang harus dilakukan oleh kepala madrasah untuk memperbaiki kualitas kerjanya.
\end{abstract}

Kata Kunci: penilaian kinerja, profesionalitas guru, supervisi kepala madrasah 


\begin{abstract}
The existence of an institution of education lies in the quality of human resources produced by it, since the establishment of an educational institution basically enhances human resources. The study was focused on the madrasah's performance-based headmaster as an effort to increase the teacher's prosthesis. This research aimed to assist teachers and school staff in doing work effectively and efficiently. The study used qualitative literature with its data-collecting systems using documenter studies, while its analysis used content analysis. The results of this study in performance assessment institutions were formal systems used to assess performance periodically, and the results could be used for decision-making in terms of development, reward, planning, compensation and motivation. The madrasah's performance assessment was expected to be useful in determining the various policies associated with improvement. The madrasah's performance assessment was a model for policymakers or stakeholders to establish career development, periodical and sustainable development. For the headmaster, the performance assessment of the headmaster was a reference to knowing what elements the headmaster should do to improve his quality of work.
\end{abstract}

Keywords: headmaster supervision, performance assessment, teacher professionality

\title{
Pendahuluan
}

Permendikbud Nomor 15 tahun 2018 tentang Pemenuhan Beban Kerja Guru, Kepala madrasah dan Pengawas Sekolah menyatakan bahwa guru, kepala madrasah dan pengawas melaksanakan beban kerja 40 jam dalam satu minggu di satuan administrasi pangkal, yang dijabarkan dalam kegiatan pokok masing-masing. Permendikbud Nomor 6 Tahun 2018 tentang Penugasan Guru Menjadi Kepala Sekolah/Madrasah menyatakan bahwa kepala madrasah adalah guru yang mendapat tugas memimpin dan mengelola satuan pendidikan. Kepemimpinan menyangkut sebuah proses pengaruh sosial yang disengaja dijalankan oleh seseorang terhadap orang lain untuk menstruktur aktivitas serta hubungan hubungan di dalam sebuah kelompok atau organisasi. Kepala Sekolah memiliki pengaruh dan memberikan pembinaan kepada tenaga administrasi sekolah. ${ }^{1}$

${ }^{1}$ Tri Yuliani dan Muhammad Kristiawan, "peran kepemimpinan kepala sekolah dalam membina kompetensi sosial (pelayanan prima) tenaga administrasi sekolah" JMKSP Journal Manajemen, Kepemimpinan, dan Supervisi Pendidikan Volume 1 No 2, Juli-Desember 2016. 
Kepala madrasah adalah pemimpin dan sekaligus penanggung jawab terselenggaranya pembelajaran yang berkualitas di sekolah/madrasah. Pembelajaran yang tinggi yang ditandai dengan kinerja yang baik. Setiap Kepala sebagai pemimpin organisasi perlu menguasai perlu menguasai dan memahami kemampuan memotivasi bawahannya, kepala sekolah agar dapat memahami bawahannya harus memahami apa yang menjadi kebutuhan bawahan. Keberhasilan pengelolaan sekolah sangat ditentukan oleh kegiatan pendayagunaan sumberdaya manusia, oleh karna itu kepala sekolah sebagai pemimpin dalam organisasi hendaknya menyadari dan tanggap untuk memelihara prestasi, ${ }^{2}$ akademik maupun nonakademik.

Oleh karena itu, kepala madrasah harus memiliki kemampuan untuk menjamin adanya proses peningkatan profesionalisme guru sekaligus melakukan penilaian kinerjanya. Salah satu upaya penting dalam pengembangan pengembangan profesionalisme dan peningkatan kinerja guru di sekolah adalah supervisi kepada guru. Oleh karena itu kepala madrasah harus memiliki pengetahuan dan keterampilan dalam pelaksanaan supervisi kepada guruPada sisi lain, guru harus dinilai kinerjanya melalui mekanisme Penilaian Kinerja Guru (PK Guru).

Merujuk pada Peraturan Menteri PAN dan RB Nomor 16 Tahun 2009, PK Guru adalah penilaian dari tiap butir kegiatan tugas utama Guru dalam rangka pembinaan karier kepangkatan dan jabatannya. Dua kegiatan tersebut memiliki tujuan dan pendekatan yang berbeda.Supervisi kepada guru lebih bersifat membantu guru dalam mengatasi kesulitan yang dihadapi agar dapat meningkatkan kualitas pembelajaran, sedangkan PK Guru lebih condong pada justifikasi kinerja guru.Berbagai pendekatan, teknik dan model supervisi kepada guru yang dilaksanakan secara simultan di sekolah diharapkan berdampak pada peningkatan motivasi dan profesionalisme guru.Salah satu bentuk peningkatan profesionalisme guru adalah kinerja guru, yang diukur dengan mekanisme PK Guru.

Gelombang peradaban keempat yang saat ini dikenal dengan era pendidik 4.o memaksa kita menyesuaikan seluruh kerangka sendi dan perangkat kerja pada setiap segmen kehidupan, termasuk pengelolaan sekolah.Perkembangan ilmu pengetahuan dan

${ }^{2}$ Donal M.F.Tiogas dan Audry. F.Walukow "Pengaruh kepemimpinan kepala sekolah, supervise dan kepuasan kerja guru terhadap kepuasan kinerja guru" Jurnal Ilmu Pendidikan Indonesia: Volume,2 No.3 Nopember 2014. 
teknologi sangat pesat menuntut kepala madrasah untuk mengembangkan kompetensinya secara berkelanjutan. Inovasi menjadi kunci paling utama di era industri 4.0 yang menuntut kepala madrasah membentuk peserta didik memiliki kompetensi abad 21 yang mampu berfikir kritis, kreatif, kolaboratif, dan komunikatif. Peserta didik yang berkualitas merupakan keluaran output dari sistem persekolahan yang baik. Kepala madrasah menjadi aktor utama yang mengelola input, proses, dan output dengan berpedoman pada Standar Nasional Pendidikan (SNP).

Salah satu kebijakan prioritas Direktorat Jenderal Guru dan Tenaga Kependidikan Kemdikbud adalah peningkatan kompetensi kepala sekolah/madrasah yang mampu berpikir visioner dalam memimpin dan mengelola sekolahnya. Target utamanya adalah membangun tata kelola dan budaya mutu di sekolah yang berdaya saing tinggi, lebih di era global dan digital seperti sekarang ini.

Kepemimpinan abad 21 bagi kepala madrasah dapat dilakukan dengan beberapa strategi.Pertama, kepala madrasah harus mampu melihat peluang dan potensi yang ada dengan mengidentifikasi masalah di sekolahnya sebagai dasar pengembangan sekolah. Yang terpenting bagi kepala madrasah adalah pelibatan secara aktif pemangku kepentingan (stakeholders) sekolah yaitu guru, tenaga kependidikan, peserta didik dan orangtua serta pihak terkait di luar sekolah untuk menyelesaikan persoalan sekolah. Kedua, kepala madrasah dalam perannya sebagai supervisor harus mampu berperan sebagai pemimpin instruksional dalam merancang dan melaksanakan pembelajaran abad 21 sesuai dengan konsep pendekatan keterampilan berpikir tingkat tinggi (higher order thinking skills). Ketiga, kepala madrasah sebagai pemimpin pendidikan abad 21 harus mampu mengajak seluruh pemangku kepentingan pendidikan di sekolah baik guru, tenaga kependidikan, maupun orangtua untuk bersama-sama mewujudkan pendidikan yang dinamis sesuai dengan perkembangan industri 4.o. Keempat, kepala madrasah harus memberikan dukungan semangat dan penghargaan kepada guru, tenaga kependidikan, dan peserta didik yang telah mencapai hasil atas prestasi, inovasi, dan pencapaian lain yang membanggakan.

\section{Pembahasan}

\section{Supervisi dan Kepemimpinan Kepala Madrasah}

Kepemimpinan merupakan salah satu hal yang sangat penting dan menarik untuk dikaji berkaitan dengan manajemen 
organisasi.Para pakar manajemen telah banyak memberikan tentang pengertian dan teori kepemimpinan dalam rangka mencapai tujuan organisasi secara efektif dan efisien, hal tersebut disebabkan organisasi tidak dapat dipisahkan dengan kepemimpinan.Berhasil tidaknya suatu organisasi salah satunya ditentukan oleh kepemimpinan yang memimpin organisasi, bahkan maju mundurnya suatu organisasi sering diidentikkan dengan perilaku kepemimpinan pimpinannya. Dengan demikian,pemimpin harus bertanggung jawab terhadap pelaksanaan organisasi atau lembaga yang dipimpin, hal ini menempatkan posisi pemimpin yang sangat penting dalam suatu organisasi atau pada lembaga tertentu. Kepemimpinan kepala sekolah yang baik akan meningkatkan motivasi kerja. ${ }^{3}$

Dalam tulisan ini, konsep perilaku kepemimpinan diarahkan pada pengamatan terhadap para pemimpin atau pimpinan berdasarkan perilakunya secara pribadi yang dimilikinya dalam memimpin suatu organisasi atau lembaga. Kemampuan perilaku secara konsepsional telah berkembang ke dalam berbagai macam cara dan berbagai macam tingkatan abstraksi. Perilaku seorang pemimpin digambarkan ke dalam istilah "pola aktifitas " peranan "manajerial", atau "kategori perilaku". ${ }^{4}$ Berdasarkan penggunaan pendekatan perilaku tersebut, para ahli banyak mengembangkan teori-teori kepemimpinan perilaku ke dalam berbagai macam klasifikasi.

Pada pembahasan konsep perilaku kepemimpinan perlu kiranya diuraikan istilah kepemimpinan.Dalam bahasa Inggris, istilah kepemimpinan diartikan leadership. Seiring dengan istilah tersebut, Soehardjono memaparkan istilah kepemimpinan (leadership) secara etimologis, leadership berasal dari kata "to lead" (bahasa: Inggris) yang artinya memimpin. Selanjutnya timbulah kata "leader" artinya pemimpin yang akhirnya lahir istilah leadership yang diterjemahkan kepemimpinan. ${ }^{5}$

\footnotetext{
${ }^{3}$ Hardono, Haryono dan Amin Yusuf, "Kepemimpinan Kepala Sekolah, Supervisi Akademik, dan Motivasi Kerja dalam Meningkatkan Kinerja Guru” Program Studi Manajemen Pendidikan Pascasarjana Universitas Negeri Semarang Indonesia. http://journal.unnes.ac.id/sju/index.php/eduman,

${ }^{4}$ Wahjosumijo.Kepemimpinan Kepala Madrasah: Tinjauan teoritik dan Permasalahannya. (Jakarta: PT. Raja Grafindo Persada, 2002) 82

${ }^{5}$ Soehardjono. Kepemimpinan: Suatu tinjauan singkat tentang Pemimpin danKepemimpinan serta Usaha-usaha Pengembangannya (Malang, APDN Malang Jawa Timur, 1981) 127
} 
Dalam Kamus Besar Bahasa Indonesia, istilah pemimpin diartikan sebagai pemuka, penuntun (pemberi contoh) atau penunjuk jalan. Jadi secara fisik pemimpin itu berada di depan. Tetapi pada hakekatnya, di manapun tempatnya,seseorang dapat menjadi pemimpin dalam memberikan pimpinan. Hal ini sesuai dengan ungkapan umum Ki Hajar Dewantoro yang terkenal "ing ngarsa asung tulodo, ing madya mangun karsa, tut wuri handayani" artinya, jika ada di depan memberikan contoh, di tengah-tengah mendorong tumbuh dan lahirnya kehendak yang nyata, sedangkan apabila berada di belakang dapat memberikan pengaruh signifikan.

Sementara itu, supervisi dalam Dictionary of Education, Good Carter (1959) memberikan pengertian bahwa supervisi adalah usaha dari petugas-petugas sekolah dalam memimpin guru-guru dan petugas-petugas lainnya dalam memperbaiki pengajaran, termasuk menstimulasi, menyeleksi pertumbuhan jabatan dan perkembangan guru-guru, merevisi tujuan-tujuan pendidikan, bahan pengajaran, metode, dan evaluasi pengajaran. ${ }^{6}$

Konsep supervisi modern dirumuskan oleh Kimball Wiles (1967) sebagai berikut:"Supervision is assistance in the devolepment of a better teaching learning situation". Supervisi adalah bantuan dalam pengembangan situasi pembelajaran yang lebih baik. Rumusan ini mengisyaratkan bahwa layanan supervisi meliputi keseluruhan situasi belajar mengajar (goal, material, technique, method, teacher, student, an envirovment $).^{7}$

Supervisi pendidikan adalah pembinaan yang berupa bimbingan atau tuntunan ke arah perbaikan situasi pendidikan pada umumnya dan peningkatan mutu mengajar dan belajar dan belajar pada khususnya. Supervisi dapat kita artikan sebagai pembinaan.Sedangkan sasaran pembinaan tersebut bisa untuk kepala madrasah, guru, pegawai tata usaha.Namun yang menjadi sasaran supervisi diartikan pula pembinaan guru.

Di era globalisasi seperti sekarang ini, semua bangsa berlomba meningkatkan sumber daya manusia yang penuh syarat dengan sumber daya pendidikan,berbagai usaha perbaikan dan peningkatan kualitas guru yang dilakukan oleh lembaga pendidikan seperti diikutkanya guru untuk mengikuti penataran-

${ }^{6}$ Piet A. Sahertian, Konsep Dasar dan Teknik Supervisi Pendidikan. (Jakarta: Rineka Cipta, 2000),57.

${ }^{7}$ M. Ngalim Purwanto, Administrasi dan Supervisi Pendidikan, cet-8, (Bandung: PT Remaja Rosdakarya, 1998), 120-122 
penataran,workshop, diklat dan seminar, semata-mata untuk meningkatkan profesionalisme guru.

\section{Penilaian Kinerja Kepala Madrasah}

Penilaian adalah suatu proses pengumpulan, pengolahan, analisis dan interpretasi data sebagai bahan dalam rangka pengambilan keputusan. Dengan demikian, dalam setiap kegiatan penilaian, ujungnya adalah pengambilan keputusan. Penilaian kinerja kepala madrasah/madrasah tidak hanya berkisar pada aspek karakter individu melainkan juga pada hal-hal yang menunjukkan proses dan hasil kerja yang dicapainya seperti kualitas, kuantitas hasil kerja, ketepatan waktu kerja, dan sebagainya. Apa yang terjadi dan dikerjakan kepala madrasah merupakan sebuah proses pengolahan input menjadi output tertentu.

Atas dasar itu, terdapat tiga komponen penilaian kinerja kepala madrasah/madrasah, yakni:

Pertama penilaian input, yaitu kemampuan atau kompetensi yang dimiliki dalam melakukan pekerjaannya. Orientasi penilaian input difokuskan pada karakteristik individu sebagai objek penilaian dalam hal ini adalah komitmen kepala madrasah terhadap pelaksanaan tugas pokok dan fungsinya. Komitmen tersebut merupakan refleksi dari kompetensi kepribadian dan kompetensi sosial kepala madrasah.

Kedua penilaian proses, yaitu penilaian terhadap prosedur pelaksanaan pekerjaan. Orientasi pada penilaian proses difokuskan kepada perilaku kepala madrasah dalam melaksanakan tugas pokok fungsi dan tanggung jawabnya, yakni melaksanakan fungsi manajerial dan fungsi supervisi pada sekolah yang dipimpinnya.

Ketiga penilaian output, yaitu penilaian terhadap hasil kerja yang dicapai dari pelaksanaan tugas pokok, fungsi dan tanggung jawabnya. Orientasi pada output dilihat dari perubahan kinerja sekolah terutama kinerja guru dan staf sekolah yang dipimpinnya.

Penekanan penilaian terhadap ketiga komponen di atas memungkinkan terjadinya penilaian kinerja yang objektif dan komprehensif.

\section{Aspek yang Dinilai dalam Penilaian Kinerja Kepala Madrasah}

Penilaian kinerja kepala madrasah dimaksudkan untuk menilai sejauhmana seorang kepala madrasah mengejawantahkan kompetensi-kompetensi yang dipersyaratkan dalam melaksanakan tugas dan fungsinya sehari-hari. Penilaian kinerja kepala madrasah difokuskan pada unsur-unsur kinerja yang terkait langsung dengan 
dimensi-dimensi kompetensi yang dipersyaratkan tersebut. Unsurunsur penilaian ini hendaknya merupakan satu kesatuan yang masing-masing memiliki bobot yang relatif sama dalam penentuan hasil akhir penilaian kinerja seorang kepala madrasah. Pada kenyataannya, setiap dimensi kompetensi kepala sekolah/ madrasah sebagaimana tercantum dalam Permendiknas Nomor 13 Tahun 2007 memiliki keluasan cakupan yang berbeda.Oleh karena itu penggunaan langsung dimensi-dimensi itu sebagai aspek penilaian kinerja kepala madrasah dapat berdampak pada kekurangsahihan hasil penilaian.

Oleh karena itu, perlu dirumuskan kembali aspek-aspek penilaian yang memiliki bobot dan ruang lingkup yang relatif sama, namun tetap dalam kerangka lima dimensi kompetensi. Perumusan aspek-aspek ini dilakukan dengan cara mengelompokkan kompentensi yang serumpun ke dalam aspek yang sama. Berdasarkan karakteristik masing-masing, kompetensi-kompetensi itu dikelompokkan ke dalam 6 aspek yakni Kepribadian dan Sosial, Kepemimpinan Pembelajaran, Pengembangan Sekolah/Madrasah, Manajemen Sumber Daya, Kewirausahaan, Supervisi Pembelajaran

\section{Perangkat Pelaksanaan Penilaian Kinerja KepalaMadrasah}

\section{Instrumen Penilaian}

Penilaian kinerja kepala madrasah/madrasah dilakukan dengan menggunakan Instrumen Penilaian Kinerja Kepala madrasah (IPKKM). Instrumen ini terdiri atas enam aspek penilaian dengan menggunakan skala penilaian 1-4 dengan rentang skor antara 6-24. Oleh karena itu untuk menyesuaikan skala panilaian dengan Permenpan nomor 16 tahun 2009 diperlukan konversi skor dengan menggunakan rumus sebagai berikut.

NKKS = NIPKKS $/ 24 \times 100$

Keterangan: NKKS = Nilai Kinerja Kepala madrasah NIPKKM $=$ Skor Instrumen Penilaian Kinerja Kepala madrasah

\section{Kategori Hasil Penilaian}

Sesuai dengan Permenpan Nomor 16 Tahun 2009, konversi hasil penilain dengan IPKKM dikonversikan ke dalam Kategori Hasil Penilaian yang dinyatakan dalam rentang nilai 1 sampai dengan 100 dan dibedakan menjadi lima kategori penilaian yaitu 'Amat Baik', 'Baik', 'Cukup', 'Sedang' dan 'Kurang' 


\section{Nilai Perolehan}

Kinerja Nilai perolehan kinerja (NPK) adalah persentase angka kredit unsur pembelajaran/bimbingan yang diperoleh yang dihitung berdasarkan kategori hasil penilaian berdasarkan IPPKM. Setiap kategori akan berimplikasi angka kredit yang diperoleh. Ketentuan NPK untuk setiap kategori hasil penilaian yakni Amat Baik 125\% Baik 100\% Cukup 75\% Sedang 50\% Kurang 25\%

\section{Supervisi Berbasis Penilaian Kinerja sebagai Upaya Peningkatan Profesionalitas Guru}

Kinerja pada dasarnya merupakan tolok ukur keberhasilan seseorang dalam melakukan suatu pekerjaan atau dalam melaksanakan tugas-tugas yang menjadi tanggung jawabnya.Banyak batasan yang diberikan oleh para ahli mengenai istilah kinerja.Secara prinsip para ahli sepakat bahwa kinerja mengarah pada suatu upaya dalam rangka mencapai prestasi kerja yang lebih baik.Maier sebagaimana dikutip oleh As'ad menjelaskan bahwa kinerja merupakan kesuksesan seseorang dalam melaksanakan suatu pekerjaan. ${ }^{8}$ Demikian ini menjelaskan bahwa kinerja adalah hasil yang dicapai seseorang menurut ukuran yang berlaku untuk pekerjaan yang bersangkutan.Kinerja seseorang dapat terlihat melalui aktifitasnya dalam melaksankan pekerjaan sehari-hari. Aktifitas ini menggambarkan bagaimana ia berusaha untuk mencapai tujuan yang telah ditetapkan. Dengan kata lain, kinerja seseorang terkait dengan bagaimana orang tersebut melaksanakan tugas hasil yang telah diraihnya.

Kinerja bisa dipandang sebagai hasil perkalian antara kemampuan dan motivasi. Kemampuan merujuk pada kecakapan seseorang dalam mengerjakan tugas-tugas tertentu. ${ }^{9}$ Sedangkan motivasi dalam kinerja merujuk pada adanya keinginan (desire) individu dalam menunjukan perilaku dan kesediaan berusaha mengingat seseorang akan mengerjakan tugas dengan cara terbaik jika memiliki kemauan serta keinginan untuk melaksanakan tugas itu dengan baik. Penjelasan tersebut mengindikasikan adanya kaitan antara kinerja guru dengan kompetensi guru, yang mana agar seorang guru memiliki tingkatan kinerja yang baik maka mutlak harus didukung dengan kompetensi yang baik pula. Persemaian antara kompetensi dengan motivasi yang dimiliki oleh

\footnotetext{
${ }^{8}$ Muhammad As'ad,Psikologi Industri (Yogyakarta: Liberty, 2007). 47.

${ }^{9}$ Muhammad Arifin Ahmad. 2007.Kinerja Guru Pembimbing Madrasah Menengah Umum. Disertasi tidak diterbitkan.PPs UNJ, 2004. 9.
} 
seorang guru pada akhirnya akan melahirkan kinerja yang baik pula.

Simamora menjelaskan bahwa kinerja merupakan kerangka acuan tingkat keberhasilan dalam mencapai persyaratanpersyaratan pekerjaan. ${ }^{10}$ Whitmore berpendapat bahwa kinerja sebagai suatu perbuatan, suatu prestasi, dan suatu pameran keterampilan. ${ }^{11}$ Dengan demikian, kinerja mengandung pengertian adanya suatu perbuatan yang ditampilkan seseorang di dalam atau selama orang tersebut melakukan aktifitas tertentu untuk mencapai tujuan.

Kinerja atau achievement merupakan terjemahan yang berasal dari bahasa Inggris yaitu "performance" yang mempunyai arti prestasi kerja hasil kerja, penampilan kerja, pelaksanaan kerja. ${ }^{12}$ Kinerja juga bisa berupa kulminasi dari tiga elemen yang masingmasing elemen tersebut saling berkaitan satu dengan yang lainnya.Adapun ketiga elemen tersebut adalah, keterampilan, upaya, dan sifat eksternal. Elemen tingkat keterampilan adalah bahan mentah yang biasa dibawa seseorang ke tempat kerjanya seperti halnya pengetahuan, kecakapan interpersonal, kecerdasan emosional, religiusitas, kemampuan, serta kecakapan-kecakapan tekhnis. Sedangkan elemen tingkat upaya adalah berupa motivasi yang diperlihatkan untuk menyelesaikan pekerjaannya.Adapun elemen yang terakhir yang berupa sifat eksternal adalah tingkatan yang menilai sejauh mana kondisi eksternal dapat mendukung kinerja seseorang. ${ }^{13}$

Kinerja menurut Vroom, sebagaimana yang dikutip oleh Mulyasa adalah fungsi perkalian antara kemauan dan motivasi. Tingkat upaya digambarkan sebagai motivasi yang diperlihatkan oleh seseorang untuk menyelesaikan pekerjaannya.Sedangkan sifat eksternal adalah tingkat sejauh mana kondisi eksternal dapat mendukung kinerja seseorang. ${ }^{14}$ Komponen-komponen dalam diri seseorang turut serta mempengaruhi kinerjanya, jika rendah pada

\footnotetext{
${ }^{10}$ Henry Simamora,Manajemen Sumber Daya Manusia. (Yogyakarta: STIE YPKN, 1995) 327

"Jhon Whitmore. Coachingfor Performance; Seni Mengarahkan Untuk Mendongkrak Kinerja. (Jakarta: Gramedia, 2007)104.

${ }^{12}$ T. R Mitchell. People In Organizational Understanding The Behavior. (Kogakhusa, McGraw-Hill, 1978) 99

${ }^{13}$ A. A. Anwar Prabu Mangkunegara,Manajemen Sumber Daya Manusia. (Bandung: Remaja Rosdakarya, 200o) 67

${ }^{14}$ Wexley dan Yukl.Perilaku Organisasi dan Psikologi Personalia.(Jakarta, PT. Bina Aksara. 1992) 112
} 
salah satu komponen maka kinerjanya akan rendah pula. Demikian pula sebaliknya, semakin tinggi seseorang pada komponen itu maka semakin tinggi pula prestasi kerjanya. ${ }^{15}$

Prestasi atau performa individu menurut Yukl adalah bergantung pada usaha dan kemampuan.Jika salah satu atau keduakeduanya rendah, maka performasi individu juga rendah. Performasi kelompok tergantung bagaimana anggota kelompok diorganisasikan untuk menggunakan keterampilannya. ${ }^{16}$ Menurut Longenecker pengendalian kinerja berarti pemantauan organisasi terhadap penetapan pencapaian tujuan dan pelaksanaan rencana. Efektivitas penetapan tujuan dan pelaksanaan rencana ini tergantung kepada sumber daya manusia dalam suatu organisasi. ${ }^{17}$ Dari penjelasan di atas dapat disimpulkan bahwa kinerja merupakan suatu hasil kerja yang diperoleh seseorang maupun organisasi, baik secara kuantitatif maupun kualitatif melalui kegiatan-kegiatan atau pengalaman-pengalaman dalam jangka waktu tertentu.

Dari beberapa pendapat di atas yang menjelaskan tentang kinerja, maka bisa dikatakan bahwa kinerja merupakan prestasi yang dicapai seseorang dalam melaksanakan tugas-tugas atau pekerjaannya sesuai dengan standar dan kriteria yang ditetapkan untuk suatu pekerjaan.

Manusia yang terlibat dalam organisasi pada dasarnya memiliki tujuan sesuai dengan jenis pekerjaannya yang harus diselaraskan dengan tujuan organisasi. Kondisi yang demikian ini merupakan suatu hal yang penting mengingat berkaitan dengan mewujudkan efektifitas dan efisiensi organisasi, yang tentunya akan tercapai apabila yang bersangkutan berkemauan dan berkemampuan mencurahkan semua potensi dirinya, baik tenaga maupun pikiran untuk mencapai tujuan organisasi.

Prestasi yang yang diperlihatkan sebagai seorang guru adalah aktifitas pembelajaran yang dapat diamati. Sedangkan tugastugas atau pekerjaan harus sesuai dengan standar yang harus dilakukan oleh guru yang mencakup persiapan, pelaksanaan, dan penilaian proses dan hasil belajar. Guru merupakan profesi atau

\footnotetext{
${ }^{15}$ Mulyasa.Manajemen Berbasis Madrasah Konsep, Strategi, dan Implementasi. (Bandung, PT. Remaja Rosdakarya, 2003) 67.

${ }^{16}$ Gary Yukl. Kepemimpinan Dalam Organisasi. Penerjemah Jusuf Udaya. (Jakarta: Prenhalindo.1994),193

${ }^{17}$ J. G. Longenecker \& C. D. Pringle, Management, $5^{\text {th }}$ ed. (Columbus, Ohio: Merril Publishing Company. 1991) 110
} 
pekerjaan yang memerlukan keahlian khusus. Pekerjaan ini tidak bisa dilakukan oleh sembarang orang yang tidak mempunyai keahlian sebagai seorang Guru.

Dengan demikian, untuk menjadi seorang Guru seseorang harus mempunyai kemampuan yang berupa keterampilan dalam melaksanakan pembelajaran. Agar dapat dilakukan dengan optimal, maka selain memiliki keterampilan, seorang Guru juga diharapkan mampu menciptakan lingkungan belajar yang efektif dan mampu mengelola kelasnya sehingga hasil belajar siswa bisa optimal dan pada gilirannya akan berimbas pada kinerja Guru yang optimal.

Guru sebagai salah satu faktor penentu kualitas pembelajaran. Guru memang mempunyai pengaruh yang cupuk dominan terhadap kualitas pembelajaran, karena gurulah yang bertanggung jawab terhadap proses pembalajar di dalam kelas, bahkan sebagai penyelenggara pendidikan di madrasah. Di antara berbagai faktor yang menentukan mutu pendidikan sepertiganya ditentukan oleh faktor Guru.

Dengan demikian, kinerja guru merupakan faktor yang dominan menentukan berhasil atau tidaknya kualitas pembelajaran. Guru yang mempunyai tingkat kinerja yang bagus maka dengan tidak langsung meningkatkan prestasi belajar siswa yang bisa dinilai dengan menggunakan evaluasi tes terhadap pelajaran yang pelajari oleh siswa tersebut. Seorang guru yang mempunyai tingkat kinerja yang bagus akan mampu menjelaskan pelajaran dengan baik, mampu menumbuhkan motivasi belajar siswa, mampu menggunakan media pembelajaan dengan baik, mampu membimbing dan mengarahkan siswa dalam pembelajaran sehingga senang dan antusias terhadap pelajaran yang diikuti.

Dalam kegiatan pembelajaran setidaknya ada tiga kemampuan pokok yang perlu dimiliki oleh tenaga pendidik, yaitu :pertama, merencanakan kegiatan belajar mengajar, kedua, mengelola kegiatan belajar mengajar, dan ketiga, menilai kegiatan belajar mengajar. ${ }^{18}$ Kemampuan-kemampuan tersebut pada dasarnya merupakan bagian tak terpisahkan yang harus dimiliki oleh seorang guru dan merupakan bagian dari kompetensi Guru. Kemampuan mengajar pada seorang guru pada dasarnya juga merupakan pencerminan penguasaan Guru terhadap kompetensinya. ${ }^{19}$ Dengan hal ini, kompetensi merupakan seperangkat

\footnotetext{
${ }^{18}$ Robert M Gagne. Essansials of Leaning by instruction. (New York Hall, Winston, 1974) 16-17.

${ }^{19}$ Imron. Pembinaan Guru di Indonesia.(Jakarta: PT. Dunia Pustaka Jaya, 1996) 74.
} 
pengetahuan dan keterampilan yang harus dimiliki oleh seseorang dalam melaksanakan tugasnya. Dengan kata lain, kemampuan dan keterampilan mempunyai peran yang erat dengan kinerja dan merupakan suatu prasyarat bagi keberhasilan dalam suatu proses perwujudan kinerja.

\section{Simpulan}

Di tangan pemimpin, aktifitas perencanaan program, pengorganisasian, pelaksanaan, pengawasan, evaluasi dan sebagainya dapat berjalan dengan baik.Kepemimpinan sekolah adalah suatu kegiatan mengarahkan, mempengaruhi dan mengendalikan seluruh potensi sekolah yang dilakukan oleh seorang kepala sekolah secara sistematis dan terprogram dalam rangka mencapai tujuan organisasi. Hasil penilaian kinerja kepala madrasah diharapkan dapat bermanfaat untuk menentukan berbagai kebijakan yang terkait dengan peningkatan mutu sekolah. Penilaian kinerja kepala madrasah merupakan acuan bagi pengambil kebijakan atau pemangku kepentingan untuk menetapkan pengembangan karir, periodeisasi dan pengembangan keprofesian berkelanjutan. Bagi kepala madrasah, penilaian kinerja kepala madrasah/madrasah merupakan acuan untuk mengetahui unsur-unsur apa saja yang harus dilakukan oleh kepala madrasah untuk memperbaiki kualitas kerjanya.

\section{Referensi}

Ahmad, Muhammad Arifin. 2004. Kinerja Guru Pembimbing Madrasah Menengah Umum. Disertasi tidak diterbitkan. PPs UNJ.

As'ad, Muhammad. 1995. Psikologi Industri. Yogyakarta: Liberty.

Haryono, Hardono, dan Amin Yusuf, "Kepemimpinan Kepala Sekolah, Supervisi Akademik, dan Motivasi Kerja dalam Meningkatkan Kinerja Guru" Program Studi Manajemen Pendidikan Pascasarjana Universitas Negeri Semarang Indonesia. http://journal.unnes.ac.id/sju/index.php/eduman, (10 Juni 2021)

Imron. 1996. Pembinaan Guru di Indonesia. Jakarta: PT. Dunia Pustaka Jaya.

J. G. Longenecker \& C. D. Pringle, Management, $5^{\text {th }}$ ed. Columbus, Ohio: Merril Publishing Company. 1991 
M Gagne, Robert. 1974. Essansials of Leaning by instruction. New York Hall, Winston.

Mangkunegara, Anwar Prabu. 200o. Manajemen Sumber Daya Manusia. Bandung: Remaja Rosdakarya.

Mulyasa. 2003. Manajemen Berbasis Madrasah Konsep, Strategi, dan Implementasi. Bandung, PT. Remaja Rosdakarya.

Purwanto, M. Ngalim. 1998. Administrasi dan Supervisi Pendidikan, cet-8, Bandung: PT Remaja Rosdakarya

Sahertian, Piet A. 200o. Konsep Dasar dan Teknik Supervisi Pendidikan. Jakarta: Rineka Cipta.

Simamora, Henry. 1995. Manajemen Sumber Daya Manusia. Yogyakarta: STIE YPKN.

Soehardjono. 1981. Kepemimpinan: Suatu tinjauan singkat tentang Pemimpin danKepemimpinan serta Usaha-usaha Pengembangannya. Malang, APDN Malang Jawa Timur.

T. R Mitchell. 1978. People In Organizational Understanding The Behavior. Kogakhusa, McGraw-Hill.

Tiogas, Donal dan Audry Walukow. "Pengaruh kepemimpinan kepala sekolah, supervise dan kepuasan kerja guru terhadap kepuasan kinerja guru" Jurnal Ilmu Pendidikan Indonesia: Volume,2 No.3 Nopember 2014. http://ejournal.uncen.ac.id/ index.php/IIPI/article/view/343

Wahjosumijo, 2002.Kepemimpinan Kepala Madrasah: Tinjauan teoritik dan Permasalahannya. Jakarta. PT. Raja Grafindo Persada.

Wexley dan Yukl. 1992. Perilaku Organisasi dan Psikologi Personalia.Jakarta: PT. Bina Aksara.

Whitmore, Jhon. 2007. Coachingfor Performance; Seni Mengarahkan Untuk Mendongkrak Kinerja. Jakarta: Gramedia.

Yukl, Gary. 1994. Kepemimpinan dalam Organisasi. Terj. Jusuf Udaya. Jakarta, Prenhalindo), cet.1o.

Yuliani Tri dan Kristiawan Muhammad, "peran kepemimpinan kepala sekolah dalam membina kompetensi sosial (pelayanan prima) tenaga administrasi sekolah" JMKSP Jurnal Manajemen, Kepemimpinan, dan Supervisi Pendidikan Volume 1 No 2, Juli-Desember 2016. 